\title{
Effect of supplementation frequency in feeding behavior, displacement patterns and forage intake of beef heifers
}

\author{
Efeito de frequências de suplementação no comportamento \\ ingestivo, padrões de deslocamento e ingestão de forragem por \\ novilhas de corte
}

\author{
Maria José de Oliveira Sichonany ${ }^{1 *}$; Marta Gomes da Rocha²; Luciana Pötter²; \\ Aline Tatiane Nunes da Rosa ${ }^{1}$; Ana Paula Binato Beltrão de Oliveria ${ }^{1}$; Laila Arruda \\ Ribeiro $^{1}$; Sheila Cristina Bosco Stivanin ${ }^{1}$; Marcos Bernardino Alves ${ }^{1}$
}

\begin{abstract}
Our work was carried out to evaluate forage intake, feeding behavior and displacement patterns of beef heifers fed exclusively on pasture or receiving oat grain, either daily ("frequent") or from Monday to Friday ("infrequent"), in two phenological stages of Alexandergrass (Urochloa plantaginea Link.): "Vegetative" and "Reproductive". The grazing method was continuous, with a variable number of animals. The experimental design was completely randomized with measures repeated in time with three feeding frequencies and two phenological stages. Forage intake was estimated using the chromic oxide technique as an indicator of fecal output. Heifers on exclusive Alexandergrass pasture and frequently supplemented had higher forage intake of dry matter (DM, $\left.2.91 \mathrm{~kg}^{\mathrm{DM}} 100 \mathrm{~kg} \mathrm{BW}^{-1}\right)$ than those that were infrequently supplemented $\left(2.00 \mathrm{~kg}^{\mathrm{DM}} 100 \mathrm{~kg} \mathrm{BW}^{-1}\right)$. Forage intake was greater in the "Vegetative" stage. The use of feeding stations is modified in response to supplementation frequency and phenological stages of Alexandergrass. Bite mass was higher for daily supplemented heifers, and these animals spent less time grazing. Also, bite mass was the item that best explained DM total ingestion. Bite mass and grazing time were similar throughout the phenological stages, whereas bite rate decreased in the reproductive stage. Feeding behavior and forage intake responses of beef heifers were influenced by supplementation frequency and phenological stages of Alexandergrass.
\end{abstract}

Key words: Feeding stations. Phenological stages. Urochloa plantaginea. White oats.

\section{Resumo}

Nos estádios fenológicos "Vegetativo" e "Reprodutivo" do papuã (Urochloa plantaginea Link.) foram avaliados a ingestão de matéria seca, o comportamento ingestivo e os padrões de deslocamento de novilhas em pastejo ou recebendo grão de aveia diariamente (frequente) ou de segunda a sexta-feira (infrequente). $\mathrm{O}$ método de pastejo foi contínuo com número variável de animais. O delineamento experimental foi inteiramente casualizado, com medidas repetidas no tempo com três frequências alimentares e dois estádios fenológicos. A ingestão de matéria seca foi estimada por meio de técnica do óxido de cromo como indicador da produção fecal. Animais em pastagem exclusiva de papuã e com

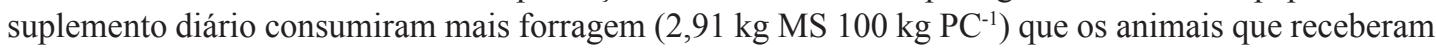

1 Discentes, Programa de Pós-Graduação em Zootecnia, Universidade Federal de Santa Maria, UFSM, Santa Maria, RS, Brasil. E-mail:maria_sichonany@hotmail.com; anunesdarosa@yahoo.com.br; anapaulaagro2012@gmail.com; laila-aribeiro@hotmail. com, sheilabosco@hotmail.com; marcossalatiel@hotmail.com

$2 \operatorname{Prof}^{\text {as }} \operatorname{Dr}^{\text {as }}$, Departamento de Zootecnia, UFSM, Santa Maria, RS, Brasil. E-mail: mgdarocha@gmail.com; potter.luciana@gmail. com

Author for correspondence 
suplemento infrequente $\left(2,00 \mathrm{~kg}\right.$ MS $\left.100 \mathrm{~kg} \mathrm{PC}^{-1}\right)$. O consumo de forragem foi maior no estádio "Vegetativo" do que no "Reprodutivo". O uso das estações alimentares é modificado em resposta as frequências de suplementação e estádios fenológicos. Novilhas que receberam suplemento diariamente pastejaram por menor tempo e colheram bocados mais pesados. A massa de bocado é o item que melhor explica a ingestão total de MS. O peso do bocado e o tempo de pastejo foram semelhantes nos estádios fenológicos do pasto enquanto a taxa de bocado diminuiu no estádio reprodutivo. Mudanças na frequência de suplementação e nos estádios fenológicos do papuã modificam o comportamento ingestivo e o consumo de forragem de novilhas de corte.

Palavras-chave: Aveia branca. Estação alimentar. Estádio fenológico. Urochloa plantaginea.

\section{Introduction}

Cultivating warm-season pastures may be a reliable approach to increase the efficiency of the cattle herd, as heifers need a high and continuous nutrient support to decrease the age at first breeding. However, even in tropical areas where pastures are available year-round, climate affects the growth and establishment of cultivated pastures, as the structure, chemical composition and phenological stages of the forage plants respond to changes in the environment (ROCHA et al., 2007). As phenological stages advance, grass quality usually falls, with an increase in levels of neutral detergent fiber and decreases in levels of crude protein and digestibility. The consequences of this effect on animal production may be minimized by feeding grazing animals supplements, which increase the harvest efficiency of grass nutrients (KRYSL; HESS, 1993), as the animals spend less time grazing and perform fewer bites (JOCHIMS et al., 2010). However, feeding supplement requires additional work and equipment, increasing the cost of animal production.

One way to rationalize the use of supplements is to decrease their feeding frequency (BERCHIELLI et al., 2006). Determining the appropriate feeding frequency requires not only the daily observation of grazing behavior, but also estimating forage intake, to understand the meaning of the complex relationships that exist when ruminants are grazing (KRYSL; HESS, 1993). Intake is influenced by characteristics related to the forage plant, grazing animal, supplement type, environment, and grazing management. Among tropical forage alternatives, Alexandergrass (Urochloa plantaginea (L.) Hitch), a common species in southern Brazil, presents structural characteristics, chemical composition and support for animal production similar to Pearl millet (Pennisetum americanum), the most cultivated annual forage in summer, even though it is considered a weed of summer crops (SOUZA et al., 2011). On the other hand, the white oat grain (Avena sativa), classified as a roughage-energy and protein-energy supplement (ZHOU et al., 1999) is an important crop in the State of Rio Grande do Sul, Brazil - the state accounts for $67 \%$ of the cultivation area of white oat in Brazil's Southern region (IBGE, 2011). However, there is no data concerning forage intake of Alexandergrass in heifers supplemented with white oat grain. Thus, our work evaluated dry matter intake, feeding behavior, and displacement patterns of beef heifers grazing Alexandergrass under different white oat grain supplementation frequencies, and assessed their relationship with the structural and chemical characteristics of Alexandergrass in its vegetative and reproductive phenological stages.

\section{Materials and Methods}

This study was carried out in the Animal Science Department at Universidade Federal de Santa Maria (UFSM), in Santa Maria, State of Rio Grande do Sul, Brazil, from January to March 2011. The Köppen climate classification in the region is humid subtropical (Cfa), and the soil is classified as Paleudalf (EMBRAPA, 2006), a type of Alfisol. 
The mean values for the chemical characteristics of the soil on the experimental area were: $\mathrm{pH}^{-\mathrm{H}_{2}} \mathrm{O}$ : 5.0; pH-SMP: 5.8; \% clay: 19.2; P: $13.4 \mathrm{mg} \mathrm{L}^{-1}$; $\mathrm{K}: 92 \mathrm{mg} \mathrm{L} \mathrm{L}^{-1}$; \%OM: 2.7; $\mathrm{Al}^{3+}$ : 0.2 cmolc L L ${ }^{-1} \mathrm{Ca}^{2+}$ : 4.6 cmolc L ${ }^{-1} ; \mathrm{Mg}^{2+}: 2.2 \mathrm{cmol} \mathrm{L}^{-1}$; base saturation: 56.6\%; Al saturation: 3\%. The meteorological data of the trial period were obtained from the UFSM Meteorological Station.

The experimental area was subdivided into six paddocks of 0.8 ha each, and a reserved area of 1.5 ha. Pasture was established through two disking and subsoiling an area with an Alexandergrass seed bank, on 27 November 2010. Fertilization consisted of $200 \mathrm{~kg} \mathrm{ha}^{-1}$ of $05-20-20$ formula (N:P:K) on December 142010 and three applications of urea (each $27 \mathrm{~kg}$ of $\mathrm{N} \mathrm{ha}^{-1}$, totaling $81 \mathrm{~kg}$ of $\mathrm{N} \mathrm{ha}^{-1}$ ), on December 14 2010, January 292011 and March 1 2011.

Treatments were: "Alexandergrass" - heifers grazing exclusively on Alexandergrass pasture; "Frequent" - heifers fed daily on Alexandergrass pasture supplemented with $0.8 \%$ DM of body weight (BW) of white oat grain; and "Infrequent" heifers fed on Alexandergrass pasture supplemented with $1.12 \% \mathrm{DM}$ of $\mathrm{BW}^{-1}$ of white oat grain from Monday to Friday. All treatments provided the same quantity of supplement on a weekly basis. The amount delivered on a given day was the result of the weekly total amount divided by the number of supplementation events for that treatment. The experimental design was completely randomized in repeated measures, with three feeding systems and two phenological stages. Four replications were used to evaluate forage intake and eight replications were used to evaluate feeding behavior and displacement patterns, in which the animals were considered as the experimental unit. For pasture evaluations, the paddock was considered as the experimental unit.

White oat grain was offered at 9:00 am and was composed of $95.8 \%$ DM, $92.1 \%$ organic matter, $13.3 \%$ crude protein, $33.4 \%$ neutral detergent fiber, $7.9 \%$ mineral matter, $76.2 \%$ digestibility, and $70.2 \%$ total digestible nutrients, as calculated according to Barber et al. (1984).

The grazing method was continuous with variable number of animals (HERINGER; CARVALHO, 2002) to allow forage mass around 2,500 to 3,000 kg DM ha-1 . Grazing started on December 27, 2010, with heifers allowed to adapt to the experimental area for nine days before beginning the trial period (on January $5^{\text {th }}, 2011$ ).

Eight Angus heifers (test animals), with mean initial age of 14 months and mean BW $252 \mathrm{~kg}$ at the beginning of trial, were used to evaluate feeding behavior, and four of them were orally dosed with chromium oxide $\left(\mathrm{Cr}_{2} \mathrm{O}_{3}\right)$ for dry mater intake estimation.

Forage mass (FM; kg DM ha ${ }^{-1}$ ) was determined by the direct visual estimation method with double sampling, and canopy height $(\mathrm{cm})$ was measured with a ruler, in parallel with FM assessment. For determination of botanical and structural composition and partial DM of Alexandergrass, forage samples were manually separated in leaf, stems (culm + leaf sheath) and inflorescence, as well as dead material and other species. This material was dried at $55^{\circ} \mathrm{C}$ for 72 hours and then weighed, to calculate the percentage and mass of each component, as well as the leaf:stem ratio.

To measure forage accumulation rate $(\mathrm{kg}$ DM ha $^{-1}$ day $^{-1}$ ), three exclusion cages were used in each paddock. Daily forage availability was obtained as the sum of forage accumulation and forage mass, divided by the number of days of each period ( 28 days). Total DM production during the experimental period was calculated as the sum of forage accumulation of each period plus the initial forage mass. Forage allowance (kg DM $100 \mathrm{~kg} \mathrm{BW}^{-1}$ ) was expressed as the forage availability divided by the stocking rate (SOLLENBERGER et al., 2005). Leaf blade allowance was obtained as the multiplication of forage allowance by the average percentage of leaf blades in forage mass. Grazing was simulated 
through the hand-plucking technique (EUCLIDES et al., 2000) and the chemical characteristics (such as dry, organic and mineral matters, and crude protein content) of the samples of forage as grazed were assessed (AOAC, 1995). The content of neutral detergent fiber (NDF) was determined according to Robertson and Van Soest (1981) as modified by Komarek (1993). The in situ digestibility of dry matter (ISDDM) was determined as described by Ørskov and McDonald (1979).

The vertical structure of the pasture was evaluated in three representative areas of the herbage mass in each experimental unit, and samples were collected in squares of $0.25 \mathrm{~m}^{2}$. In each square, the forage was cut and samples were collected along three strata, $10 \mathrm{~cm}$ each, from the top to the bottom of the sward. This material was manually separated into stem, leaf blade, dead material and inflorescence components. The components were then oven-dried (at $65{ }^{\circ} \mathrm{C}$ for 72 hours) and weighed to calculate the bulk density of each component, expressed in $\mathrm{g} \mathrm{cm}^{-3}$.

The animals were weighed at intervals of 28 days, with a 12-hour solids and liquids fasting. On the same dates, body condition score (BCS) was rated according to Lowman et al. (1973). The stocking rate was calculated as the sum of the average weight of the test animals plus the average weight of each regulator animal, multiplied by the number of days that each regulator remained on the paddock, divided by the total number of days of the study period.

Forage intake was evaluated during the "Vegetative" (January 15- 26) and "Reproductive" (March 12-23) stages of the grass. Chromium oxide $(10 \mathrm{~g})$ was orally administered daily, at 12:00 am, for 12 days (eight days for adaptation and four days for collection of fecal samples). Chromium levels in dried feces were determined by atomic absorption spectrophotometry, as adapted by Kozlozki et al. (1998). To estimate fecal output, the formula: FO $=$ administrated chromium $\left(\mathrm{g}\right.$ day $\left.^{-1}\right) /$ chromium in feces $\left(\mathrm{g} \mathrm{DM} \mathrm{kg}^{-1}\right.$ ) (POND et al. 1989) was employed. Forage intake (FI; kg DM day ${ }^{-1}$ ) was determined as: $\mathrm{FI}=$ fecal production/1 - digestibility. Forage intake was also expressed as a percentage of the body weight (BW). With these data, we calculated the total intake, forage intake, NDF from the forage, crude protein, total NDF (forage NDF + supplement NDF) and total crude protein (forage $\mathrm{CP}+$ supplement $\mathrm{CP}$ ) intake, in $\mathrm{kg}$ DM $100 \mathrm{~kg} \mathrm{BW}^{-1}$ (ELOY et al., 2014).

The feeding behavior and displacement patterns of the heifers were assessed during the grazing periods on January 25 ("Vegetative") and March 24 ("Reproductive"). Ingestive behavior was assessed by 24 hours of visual observation of test animals on January 28 (Vegetative) and March 23 (Reproductive). Grazing, ruminating, time at the trough and other activities were recorded at every tenminute interval (JAMIESON; HODGSON, 1979) and expressed as total time per day (minute day $\left.^{-1}\right)$. The time spent by the animals to select and harvest the forage, including the short periods used in the displacement for forage selection, was considered as grazing time. The time spent by the animals eating the supplement was counted as trough time. The ruminating time refers to the cessation of the feeding process and activities of chewing without searching for and apprehending forage. Idling time refers to when the animals were resting (FORBES, 1988). Concomitantly with the grazing activities during morning and afternoon, the time spent by the animals to perform twenty bites (FORBES; HODGSON, 1985) was registered as many times as possible. These data were used to calculate the bite rate (bite minute ${ }^{-1}$ ). The daily number of bites (bites day $^{-1}$ ) was obtained by multiplying the bite rate by the daily grazing time (minutes day ${ }^{-1}$ ).

The displacement patterns of beef heifers were observed in five cycles of ten feeding stations. The feeding station was defined as the space corresponding to grazing without movement of the forelegs (LACA et al., 1992), while the step was defined as each movement of the forelegs. These 
data were used to calculate the number of visited feeding stations per minute, the time remained in each feeding station, the number of steps between stations and the number of steps per minute (displacement). The number of bites per station was calculated by dividing the number of daily bites by the daily number of feeding stations. The bite mass (g DM bite ${ }^{-1}$ ) values were estimated by the equation: $\mathrm{BM}=\mathrm{I} /(\mathrm{GT} * \mathrm{BR})$, where: $\mathrm{BM}=$ bite mass $(\mathrm{g} \mathrm{DM}) ; \mathrm{I}=\mathrm{DM}$ intake $\left(\mathrm{g} \mathrm{day}^{-1}\right) ; \mathrm{BR}=$ bite rate $\left(\right.$ bite $\left.\min ^{-1}\right)$; GT $=$ grazing time $\left(\operatorname{min~day~}^{-1}\right)$ (JAMIESON; HODGSON, 1979).

A completely randomized design with repeated measures was used with four replications to evaluate forage intake and eight replications to evaluate feeding behavior and displacement patterns. In these evaluations, the animals were considered replicates.

Data were subjected to analysis of variance, mean comparisons and test of contrasts. We used the Tukey test with $10 \%$ significance to compare treatment effects. In the multiple regression analysis, we used the Stepwise procedure to identify independent variables that influence the dependent variables. All possible equations were obtained and one was selected following some criteria: minor p-value and minor number of independent variable. Analyses were performed using the statistical package SAS v 9.1.3.

The mathematical model for forage intake, feeding behavior and displacement patterns were represented by the following equation: $\gamma_{\mathrm{ijk}}=\mu+$ $\tau_{i}+\alpha_{j}+(\tau \alpha)_{i j}+\lambda_{k}\left(\tau_{i}\right)+\varepsilon_{i j k}$. In the model, $\gamma_{i j k}$ represents dependent variables; $\mu$ is the mean of all observations; $\tau_{i}$ corresponds to the effect of the $i^{\text {th }}$ feeding frequency; $\alpha_{j}$ is the effect of the $j^{\text {th }}$ growth stage; $(\tau \alpha)_{\mathrm{ij}}$ represents the interaction between the $\mathrm{i}^{\text {th }}$ feeding frequency and $\mathrm{j}^{\text {th }}$ growth stage; $\lambda_{\mathrm{k}}\left(\tau_{\mathrm{i}}\right)$ is the effect of $\mathrm{k}^{\text {th }}$ replication within the $\mathrm{i}^{\text {th }}$ feeding frequency (error a); $\varepsilon_{\mathrm{ijk}}=$ residual random error (error b).

\section{Results}

The maximum $\left(30^{\circ} \mathrm{C}\right)$, minimum $\left(14^{\circ} \mathrm{C}\right)$ and average $\left(24^{\circ} \mathrm{C}\right)$ temperatures of January, February, and March during the study period were similar to the normal historical average. Rainfall was $9.6 \%$ (21.7 mm), 50.8\% (65.2 $\mathrm{mm}$ ) and 51.9\% (78.4 mm) above the historical averages in January, February and March, respectively. Insolation was $43.6 \%$ (98.1 hours), 30.9\% (74.2 hours) and 72.2\% (142.6 hours) below historical averages for the same months (INMET, 2011).

Therewasnointeractionbetweensupplementation frequencies and phenological stages for the pasture variables $(p>0.10)$. Forage mass $\left(2,711 \mathrm{~kg} \mathrm{DM}\right.$ ha $^{-}$ ${ }^{1}$ ), forage allowance $\left(8.9 \mathrm{~kg} \mathrm{DM} 100 \mathrm{~kg}\right.$ of $\left.\mathrm{BW}^{-1}\right)$, leaf blades allowance $\left(3.2 \mathrm{~kg}\right.$ DM $\left.100 \mathrm{~kg} \mathrm{BW}^{-1}\right)$, canopy height $(13.1 \mathrm{~cm})$, leaf blade:stem ratio (0.9), neutral detergent fiber (67.4\% of DM) and in situ DM digestibility ( $57.8 \%$ of DM) were not different ( $p>0.10$ ) when heifers were subjected to different supplementation frequency. Forage as grazed by heifers infrequently supplemented had 20.3\% (p $=0.0242$ ) greater crude protein content than either forage as grazed by heifers that were daily fed or forage as grazed by heifers exclusively fed on Alexandergrass, both of which had similar protein contents.

The crude protein content $(11.2 \%$ of DM) of the forage as grazed and the forage allowance were similar for both phenological stages of Alexandergrass, but forage mass $(p=0.0023)$ and neutral detergent fiber (Table 1) were, respectively, $41.3 \%$ and $4.6 \%$ lower in the vegetative stage than the reproductive stage. On the other hand, leaf blades allowance, canopy height, leaf blade: stem ratio and in situ DM digestibility were, respectively, $48.9 \%$, $35.2 \%$, $66.7 \%$ e $14.7 \%$ greater in the vegetative stage of Alexandergrass than in the reproductive stage (Table 1). 
Table 1. Structural and qualitative parameters of Alexandergrass at "Vegetative" (V) and "Reproductive" (R) phenological stages, grazed by heifers receiving "Frequent" and "Infrequent" supplementation.

\begin{tabular}{|c|c|c|c|c|c|c|c|c|}
\hline \multirow{2}{*}{ Variable } & \multirow{2}{*}{ Treatment } & \multicolumn{2}{|c|}{ Phenological stage } & \multirow{2}{*}{ Mean } & \multirow{2}{*}{$\mathrm{p}^{*}$} & \multirow{2}{*}{$\mathrm{p}^{* *}$} & \multirow{2}{*}{$\mathrm{p}^{* * *}$} & \multirow{2}{*}{ Error } \\
\hline & & $\mathrm{V}$ & $\mathrm{R}$ & & & & & \\
\hline \multirow{4}{*}{$\begin{array}{l}\text { Leaf blade } \\
\text { allowance }^{1}\end{array}$} & Alexandergrass & 3.77 & 2.59 & 3.18 & & & & \\
\hline & Frequent & 4.40 & 1.51 & 2.95 & 0.2254 & 0.0090 & 0.1144 & 0.36 \\
\hline & Infrequent & 4.82 & 2.38 & 3.19 & & & & \\
\hline & Mean & 4.23 & 2.16 & & & & & \\
\hline \multirow{4}{*}{$\begin{array}{l}\text { Canopy } \\
\text { height }^{2}\end{array}$} & Alexandergrass & 16.15 & 10.20 & 13.17 & & & & \\
\hline & Frequent & 15.65 & 10.40 & 13.02 & 0.9610 & 0.0032 & 0.9082 & 0.87 \\
\hline & Infrequent & 15.95 & 10.35 & 13.15 & & & & \\
\hline & Mean & 15.92 & 10.32 & & & & & \\
\hline \multirow{4}{*}{$\begin{array}{l}\text { Leaf: stem } \\
\quad \text { ratio }\end{array}$} & Alexandergrass & 1.12 & 0.51 & 0.81 & & & & \\
\hline & Frequent & 1.56 & 0.49 & 0.84 & 0.1494 & 0.0812 & 0.4258 & 0.16 \\
\hline & Infrequent & 1.64 & 0.57 & 1.10 & & & & \\
\hline & Mean & 1.36 & 0.51 & & & & & \\
\hline \multirow{4}{*}{$\mathrm{NDF}^{3}$} & Alexandergrass & 66.73 & 69.23 & 67.98 & & & & \\
\hline & Frequent & 65.90 & 68.17 & 67.03 & 0.5504 & 0.0176 & 0.3868 & 0.58 \\
\hline & Infrequent & 64.72 & 69.37 & 67.05 & & & & \\
\hline & Mean & 65.78 & 68.92 & & & & & \\
\hline \multirow{4}{*}{$\mathrm{CP}^{3}$} & Alexandergrass & 10.08 & 10.04 & $10.06 \mathrm{~b}$ & & & & \\
\hline & Frequent & 10.56 & 11.26 & $10.91 \mathrm{~b}$ & 0.0242 & 0.8648 & 0.8804 & 0.40 \\
\hline & Infrequent & 12.72 & 12.49 & $12.61 \mathrm{a}$ & & & & \\
\hline & Mean & 11.12 & 11.26 & & & & & \\
\hline \multirow{4}{*}{ IVDDM $^{3}$} & Alexandergrass & 62.56 & 50.83 & 56.70 & & & & \\
\hline & Frequent & 61.45 & 56.05 & 58.75 & 0.3567 & 0.0119 & 0.3876 & 1.55 \\
\hline & Infrequent & 63.23 & 52.86 & 58.04 & & & & \\
\hline & Mean & 62.41 & 53.25 & & & & & \\
\hline
\end{tabular}

${ }^{1}$ Percentage of body weight; ${ }^{2}$ centimeters; ${ }^{3}$ Percentage of dry matter

Means followed by the same lower case letters on the column are not different $(p>0.10)$ by Tukey test

*Probability of supplementation frequency; **Probability of phenological stages; ***Probability of supplementation frequency $\times$ phenological stages interaction

The densities of leaf blades (3.6 and $0.93 \mathrm{~g} \mathrm{DM}$ $\mathrm{cm}^{-3}$ ), stems ( 9.4 and $0.8 \mathrm{~g} \mathrm{DM} \mathrm{cm}^{-3}$ ), dead material (4.8 and $0.4 \mathrm{~g} \mathrm{DM} \mathrm{cm}^{-3}$ ) and inflorescences (1.2 and $0.3 \mathrm{~g} \mathrm{DM} \mathrm{cm}^{-3}$ ) of grass from, respectively, $0-10$ and $10-20 \mathrm{~cm}$ strata, were similar in plots where heifers received different supplementation frequencies. In the $0-10 \mathrm{~cm}$ stratum, leaf blades and stems bulk density were, respectively, $49.5 \%$ and $40.7 \%$ greater, in the vegetative stage than in the reproductive stage (Figure 1). For the 10-20 cm stratum there was no difference $(\mathrm{p}>0.10)$ in bulk densities of leaf blades, stems and dead material between phenological stages, with mean values of $0.9,0.8$ and $0.3 \mathrm{~g} \mathrm{DM} \mathrm{cm}^{-3}$, respectively.

Heifers that received daily supplement grazed for 102.7 minutes less, in addition to the 30 minutes that they spent at the trough, but remained idling for 113.5 additional minutes $(21.7 \%)$, compared to the heifers in the other two feeding systems. Heifers 
that received supplement, whether frequently or period of time (29.7 min Table 2$)$ without any return infrequentely, stayed at the trough for a similar during the 24 hours of observation.

Figure 1. Bulk density $\left(\mathrm{g} \mathrm{cm}^{-3}\right.$ of DM) of Alexandergrass structural components at the Vegetative and Reproductive phenological stages.

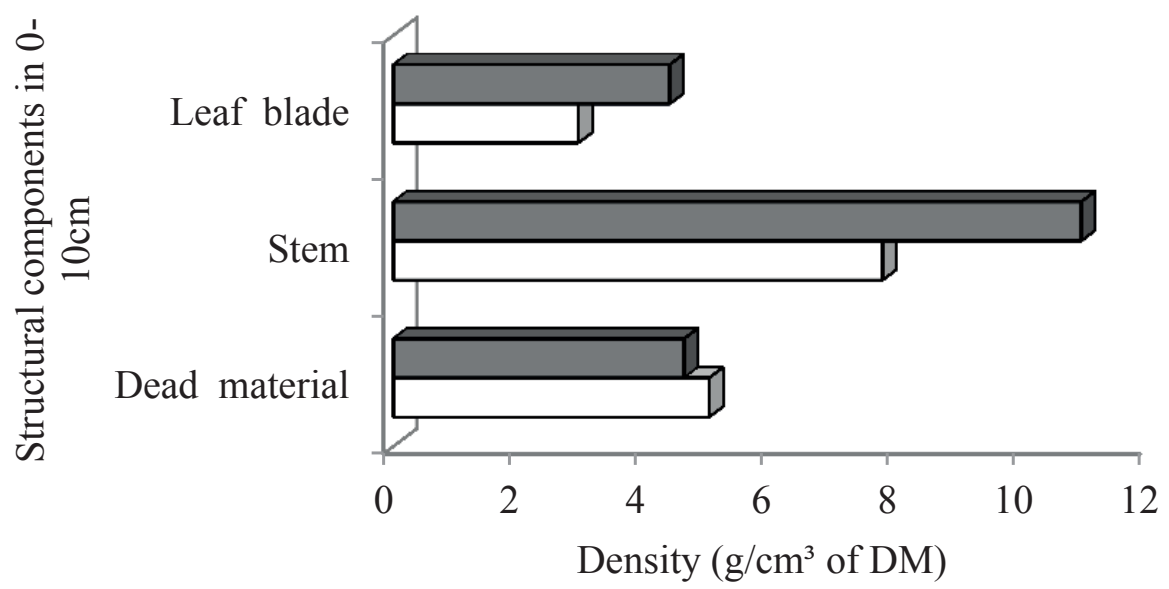

$\square$ Vegetative

$\square$ Reproductive

Table 2. Ingestive behaviour of beef heifers under different supplementation frequencies ("Frequent" and "Infrequent") at the "Vegetative" (V) and "Reproductive" (R) phenological stages of Alexandergrass.

\begin{tabular}{|c|c|c|c|c|c|c|c|c|}
\hline \multirow{2}{*}{ Variable } & \multirow{2}{*}{ Treatment } & \multicolumn{2}{|c|}{ Phenological stage } & & \multirow{2}{*}{$\mathrm{p}^{*}$} & \multirow{2}{*}{$\mathrm{p}^{* *}$} & \multirow{2}{*}{$\mathrm{p}^{* * *}$} & \multirow{2}{*}{ Erro } \\
\hline & & $\mathrm{V}$ & $\mathrm{R}$ & & & & & \\
\hline \multirow{4}{*}{$\begin{array}{c}\text { Grazing } \\
\text { time }^{1}\end{array}$} & Alexandergrass & 450.7 & 498.3 & $474.5 \mathrm{a}$ & & & & \\
\hline & Frequent & 330.5 & 352.0 & $341.3 \mathrm{~b}$ & 0.0046 & 0.3449 & 0.4789 & 12.91 \\
\hline & Infrequent & 419.1 & 407.9 & $413.5 \mathrm{a}$ & & & & \\
\hline & Mean & 400.1 & 425.5 & & & & & \\
\hline \multirow{4}{*}{$\begin{array}{l}\text { Rumina- } \\
\text { tion time }\end{array}$} & Alexandergrass & 421.15 & 445.05 & 433.10 & & & & \\
\hline & Frequent & 479.49 & 372.90 & 426.19 & 0.2385 & 0.0528 & 0.3509 & 14.24 \\
\hline & Infrequent & 481.05 & 488.85 & 484.95 & & & & \\
\hline & Mean & 460.53 & 441.30 & & & & & \\
\hline \multirow{4}{*}{ Idle time ${ }^{1}$} & Alexandergrass & 568.3 & 496.6 & $532.5 \mathrm{~b}$ & & & & \\
\hline & Frequent & 597.1 & 687.6 & $635.9 \mathrm{a}$ & 0.0204 & 0.6948 & 0.1339 & 17.56 \\
\hline & Infrequent & 503.7 & 520.9 & $512.3 \mathrm{~b}$ & & & & \\
\hline & Mean & 556.3 & 557.5 & & & & & \\
\hline \multirow{4}{*}{$\begin{array}{l}\text { Trough } \\
\text { time }^{1}\end{array}$} & Alexandergrass & 0.0 & 0.0 & 0.0 & & & & \\
\hline & Frequent & 32.9 & 27.4 & 30.2 & 0.7792 & 0.0473 & 0.2097 & 2.66 \\
\hline & Infrequent & 36.1 & 22.3 & 29.2 & & & & \\
\hline & Mean & 34.5 & 24.9 & & & & & \\
\hline
\end{tabular}

Continue... 
Continuation...

\begin{tabular}{ccccccccc}
\hline & Alexandergrass & 0.37 & 0.45 & $0.41 \mathrm{~b}$ & & & & \\
Bite mass $^{2}$ & Frequent & 0.55 & 0.60 & $0.57 \mathrm{a}$ & 0.0118 & 0.3433 & 0.7970 & 0.03 \\
& Infrequent & 0.34 & 0.35 & $0.34 \mathrm{~b}$ & & & & \\
& Mean & 0.41 & 0.45 & & & & & \\
\hline \multirow{3}{*}{ Bite rate $^{3}$} & Alexandergrass & 48.8 & 39.1 & $43.9 \mathrm{ab}$ & & & & \\
& Frequent & 47.4 & 42.0 & $45.1 \mathrm{a}$ & 0.0427 & 0.0001 & 0.5175 & 0.88 \\
& Infrequent & 46.0 & 37.7 & $41.9 \mathrm{~b}$ & & & & \\
& Mean & 47.4 & 39.4 & & & & & \\
\hline
\end{tabular}

${ }^{1}$ minutes, ${ }^{2}$ gram of DM, ${ }^{3}$ bite per minute

Means followed by the same lower case letters on the column are not different ( $\mathrm{p}>0.10)$ by Tukey test

*Probability of supplementation frequency; **Probability of phenological stages; ***Probability of supplementation frequency $\times$ phenological stages interaction.

Grazing (412.8 minutes) and idling (556.9 minutes) times for both phenological stages of Alexandergrass were similar (Table 2). Rumination time (448.1 min) was similar among the different supplementation frequencies and phenological stages of Alexandergrass. Heifers consumed the supplement faster in the reproductive stage of Alexandergrass, staying 9.6 minutes less in the trough, $27.9 \%$ less time than during the vegetative stage.

In a similar pasture structure (Table 1), daily supplemented heifers performed 3.2 more bites per minute than those who received infrequent supplement (Table 2). Heifers fed exclusively on pasture performed a similar number of bites to those that received the supplement, regardless of frequency of supplementation. In the vegetative stage of Alexandergrass, heifers performed 8.0 more bites than in the reproductive stage.

Infrequently supplemented heifers remained 2.5 more seconds in each feeding station than heifers that remained exclusively on Alexandergrass and those that received daily supplementation (Table 3 ). Daily supplemented heifers visited 1.6 additional feeding stations per minute than the heifers that were supplemented infrequently. Heifers exclusively on pasture visited a similar number of feeding stations per minute when compared to those that were supplemented.

The number of steps performed between each feeding station and a number of steps per minute were not different for either supplementation frequency, with an average of 1.6 and 11.8 steps, respectively. In the reproductive stage of Alexandergrass, the heifers stayed 4.2 additional seconds per feeding station, visited 2.6 fewer stations per minute, and walked 6.5 fewer steps per minute than in the vegetative stage. The number of steps that heifers performed between each feeding station was similar $(p=0.1050)$ in the Alexandergrass phenological stages, with an average of 1.6 steps (Table 3 ). 
Table 3. Displacement patterns of beef heifers under supplementation frequencies ("Frequent" and "Infrequent") at the "Vegetative" (V) and "Reproductive" (R) phenological stages of Alexandergrass.

\begin{tabular}{ccccccccc}
\hline \multirow{2}{*}{ Variable } & Treatment & \multicolumn{2}{c}{ Phenological stage } & \multirow{2}{*}{ Mean } & p* & p** & \multirow{2}{*}{$\mathrm{p}^{* * *}$} & \multirow{2}{*}{ Error } \\
\cline { 3 - 6 } & & $\mathrm{V}$ & $\mathrm{R}$ & & & & & \\
& Alexandergrass & 7.85 & 10.38 & $9.11 \mathrm{~b}$ & & & & \\
& Frequent & 6.93 & 12.37 & $9.26 \mathrm{~b}$ & 0.0114 & 0.0001 & 0.2836 & 0.50 \\
& Infrequent & 9.34 & 12.80 & $11.72 \mathrm{a}$ & & & & \\
& Mean & 8.04 & 12.28 & & & & & \\
\hline Feed station/minute & Alexandergrass & 8.80 & 6.73 & $7.76 \mathrm{ab}$ & & & & \\
& Frequent & 9.69 & 5.89 & $8.06 \mathrm{a}$ & 0.0898 & 0.0001 & 0.3266 & 0.32 \\
& Infrequent & 7.52 & 5.41 & $6.47 \mathrm{~b}$ & & & & \\
& Mean & 8.67 & 6.02 & & & & & \\
\hline Steps/minute & Alexandergrass & 14.55 & 9.54 & $12.04 \mathrm{a}$ & & & & \\
& Frequent & 17.32 & 8.21 & $13.41 \mathrm{a}$ & 0.1068 & 0.0001 & 0.3887 & 0.74 \\
& Infrequent & 12.71 & 7.73 & $10.00 \mathrm{a}$ & & & & \\
& Mean & 14.86 & 8.36 & & & & & \\
\hline
\end{tabular}

${ }^{1}$ Seconds

Means followed by the same lower case letters on the column are not different $(p>0.10)$ by Tukey test

*Probability of supplementation frequency; **Probability of phenological stages; ***Probability of supplementation frequency $\mathrm{x}$ phenological stages interaction.

The total DM intake did not differ between supplementation frequencies and was equivalent to $3.2 \%$ of BW (Table 4). In the contrast analysis, however, heifers that were supplemented, regardless of frequency, showed $19.0 \%$ higher total ingestion than heifers that remained exclusively on pasture $(\mathrm{p}=0.0084)$. Bite mass $(\mathrm{BM})$ was the item that best explained the total ingestion (Total ingestion $=1.31+3.84 \mathrm{BM} ; \mathrm{p}=0.0030 ; \mathrm{r}^{2}=0.92$ ). Heifers that were exclusively on pasture and those that received frequent supplementation ingested $45.8 \%$ more forage $(0.9 \% \mathrm{BW})$ than the heifers that received infrequent supplementation (Table 4). CP ingestion (from forage) was similar in the different supplementation frequencies and in the Alexandergrass phenological stages, averaging 0.3 $\mathrm{kg}$ DM $100 \mathrm{~kg} \mathrm{BW}^{-1}$. BM was $0.2 \mathrm{~g}$ greater when heifers were daily supplemented compared to heifers grazing exclusively on Alexandergrass and to those that infrequently received the supplement (Table 2). BM was similar for both phenological stages of Alexandergrass, with an average of $0.4 \mathrm{~g}$ DM bite ${ }^{-1}$. 
Table 4. Forage intake by beef heifers under supplementation frequencies ("Frequent" and "Infrequent") at the "Vegetative" (V) and "Reproductive" (R) phenological stages of Alexandergrass.

\begin{tabular}{|c|c|c|c|c|c|c|c|c|}
\hline \multirow{2}{*}{ Intake $^{1}$} & \multirow{2}{*}{ Treatment } & \multicolumn{2}{|c|}{ Stage } & \multirow{2}{*}{ Mean } & \multirow{2}{*}{$\mathrm{p}^{*}$} & \multirow{2}{*}{$\mathrm{p}^{* *}$} & \multirow{2}{*}{$\mathrm{p}^{* * *}$} & \multirow{2}{*}{ Error } \\
\hline & & $\mathrm{V}$ & $\mathrm{R}$ & & & & & \\
\hline \multirow{4}{*}{ Total } & Alexandergrass & 3.09 & 3.00 & 3.05 & & & & \\
\hline & Frequent & 3.64 & 3.57 & 3.58 & 0.1600 & 0.0532 & 0.1329 & 0.10 \\
\hline & Infrequent & 3.49 & 2.76 & 3.12 & & & & \\
\hline & Mean & 3.37 & 3.06 & & & & & \\
\hline \multirow{4}{*}{ Grass } & Alexandergrass & 3.09 & 3.00 & $3.05 \mathrm{a}$ & & & & \\
\hline & Frequent & 2.84 & 2.77 & $2.78 \mathrm{a}$ & 0.0067 & 0.0532 & 0.1329 & 0.13 \\
\hline & Infrequent & 2.37 & 1.64 & $2.00 \mathrm{~b}$ & & & & \\
\hline & Mean & 2.75 & 2.44 & & & & & \\
\hline \multirow{4}{*}{$\begin{array}{l}\text { NDF of } \\
\text { Grass }\end{array}$} & Alexandergrass & 2.04 & 2.09 & $2.06 \mathrm{a}$ & & & & \\
\hline & Frequent & 1.86 & 1.88 & $1.87 \mathrm{a}$ & 0.0071 & 0.2405 & 0.1297 & 0.09 \\
\hline & Infrequent & 1.53 & 1.13 & $1.33 \mathrm{~b}$ & & & & \\
\hline & Mean & 1.80 & 1.68 & & & & & \\
\hline \multirow{4}{*}{$\mathrm{CP}$ of Grass } & Alexandergrass & 0.31 & 0.30 & 0.30 & & & & \\
\hline & Frequent & 0.30 & 0.32 & 0.31 & 0.1239 & 0.3111 & 0.1570 & 0.01 \\
\hline & Infrequent & 0.30 & 0.21 & 0.26 & & & & \\
\hline & Mean & 0.30 & 0.28 & & & & & \\
\hline \multirow{4}{*}{ NDF Total } & Alexandergrass & 2.04 & 2.09 & $2.06 \mathrm{ab}$ & & & & \\
\hline & Frequent & 2.14 & 2.16 & $2.15 \mathrm{a}$ & 0.0829 & 0.2355 & 0.1297 & 0.07 \\
\hline & Infrequent & 1.90 & 1.51 & $1.70 \mathrm{~b}$ & & & & \\
\hline & Mean & 2.01 & 1.89 & & & & & \\
\hline \multirow{4}{*}{ CP Total } & Alexandergrass & 0.31 & 0.30 & $0.30 \mathrm{~b}$ & & & & \\
\hline & Frequent & 0.41 & 0.42 & $0.41 \mathrm{a}$ & 0.0039 & 0.3265 & 0.1768 & 0.01 \\
\hline & Infrequent & 0.45 & 0.36 & $0.40 \mathrm{a}$ & & & & \\
\hline & Mean & 0.38 & 0.35 & & & & & \\
\hline
\end{tabular}

${ }^{1} \mathrm{~kg} \mathrm{DM} 100 \mathrm{~kg} \mathrm{BW}^{-1}$

Means followed by the same lower case letters on the column are not diferent $(p>0.10)$ by Tukey test

*Probability of supplementation frequency; **Probability of phenological stages; ***Probability of supplementation frequency $\mathrm{x}$ phenological stages interaction.

Heifers fed exclusively on pasture and those that received daily supplementation consumed $0.6 \%$ more forage NDF than the heifers that were infrequently supplemented. The total consumption of NDF (forage NDF + supplement NDF) was $0.4 \% \mathrm{~kg}$ DM $100 \mathrm{~kg} \mathrm{BW}^{-1}$ higher when heifers were supplemented daily compared to those who received the infrequent supplementation. Heifers exclusively on Alexandergrass pasture consumed the same amount of total NDF compared to those that received supplementation regardless of frequency and Alexandergrass phenological stages, with average of $2.0 \mathrm{~kg} \mathrm{DM} 100 \mathrm{~kg} \mathrm{BW}^{-1}$. The total intake of crude protein (forage $\mathrm{CP}+$ supplement $\mathrm{CP}$ ) was $35 \%$ greater when heifers were supplemented, regardless of frequency. This consumption was similar in the different Alexandergrass phenological stages, with an average of $0.4 \mathrm{~kg}$ DM $100 \mathrm{~kg} \mathrm{BW}^{-1}$. 


\section{Discussion}

The values of forage mass, sward height, and forage allowance in this study were lower than those observed by Costa et al. (2011), Souza et al. (2012) and Oliveira Neto et al. (2013) using the same forage. However, the heifers in these studies gained from 0.483 to $0.766 \mathrm{~kg} \mathrm{BW}$ daily, which is comparable with the $0.732 \mathrm{~kg} \mathrm{day}^{-1}$ gained by heifers exclusively grazing in our study, showing that the scale of variation of values for daily weight gain is small in response to different canopy components and the same animal performance is achieved with different sward managements. The value of leaf blades allowance (Table 4) was higher than the forage intake value predicted by the National Research Council (NRC, 2001). Thus, the canopy characteristics were not a limiting factor for forage consumption.

The crude protein content of the forage as grazed meets the requirements for the heifer category (NRC, 2001). The content of neutral detergent fiber is within the range found in the literature for tropical pastures, which is reported to be between 53.2\% (SOUZA et al., 2011) and 71.5\% (OLIVEIRA NETO et al., 2013), and is above the critical limit of $55-60 \%$ of NDF (VAN SOEST, 1994), which may cause a smaller cell wall degradation in the rumen and a lower rate of passage through the gastrointestinal tract.

The longer grazing time of the heifers receiving infrequent supplement, compared to heifers receiving supplement daily, might be explained by their anticipatory behavior, that they may not receive the supplement, which makes these animals behave more closely to the heifers that grazed exclusively.

Heifers spent similar time grazing and in other activities at both vegetative and reproductive states of Alexandergrass, even though the canopy structure changed between phenological stages. In grazing systems, the ingestion of large amounts of supplements, quickly and at once, can cause digestive disturbances in the animals, with a consequent reduction in fiber digestion and forage intake (CATON; DHUYVETTER, 1997). This is what probably occurred in the reproductive stage of Alexandergrass, when the supplement was consumed in a shorter time. The rumination time, however, is influenced by the consumption of neutral detergent fiber (WELCH; HOOPER, 1988), which explains the similar values for rumination time regardless of the animals receiving supplement or not, and among phenological stages of the grass.

Modifications in the number of bites are related to the number of mandibular movements to apprehend and handle forage (PENNING et al., 1991). The $4.8 \%$ increase in NDF content of the harvested forage and the reduction of $95.8 \%$ and $17.2 \%$ in the leaf blades allowance and in situ DM digestibility, respectively, in the reproductive stage of Alexandergrass, led the heifers to increase forage handling time, thus explaining the reduction in the bite rate at this stage.

Carvalho et al. (1999) argue that the permanence of herbivores at the feeding station and the number of visited feeding stations are related to forage availability, characterizing forage selection by the animal. However, this explanation, related to pasture structural characteristics, is not applicable to our results, as the forage mass, the leaf blades allowance and the canopy height (Table 1) were similar in the different supplementation frequencies. In our case, this displacement behavior is probably explained by the fact that heifers on infrequent supplementation received $0.32 \mathrm{~kg}$ DM $100 \mathrm{~kg} \mathrm{BW}^{-1}$ more supplement from Monday to Friday than the daily supplemented heifers and, when compared to heifers exclusively on Alexandergrass, received $1.12 \mathrm{~kg}$ DM 100 $\mathrm{kg} \mathrm{BW}^{-1}$ more. The animal always displaces itself seeking to maximize its herbage ingestion (PRACHE et al., 1998). The decrease in leaf blades bulk density (Figure 1) in the grazeable stratum in the reproductive stage of Alexandergrass promoted the greatest length of time spent by heifers at each feeding station, corresponding to longer periods selecting green leaves within this stratum. Hence, 
the heifer adjusts its grazing behavior in accordance to the availability of its preferred grass components, leaf blades, and their spatial distribution in the canopy (MANNETJE; EBERSOHN, 1980).

Considering the average daily gain of heifers of $0.821 \mathrm{~kg}$ in this study, the observed intake was $15.7 \%$ greater than the DM intake estimated by the National Research Council (NRC, 2001), of 2.81 $\mathrm{kg}$ DM $100 \mathrm{~kg} \mathrm{BW}^{-1}$ for 18 months old heifers. For the infrequent supplementation, even the largest amount of supplement (1.12\% of BW) did not result in similar forage ingestion in the Alexandergrass phenological stages, with the total ingestion $0.31 \mathrm{~kg}$ DM $100 \mathrm{~kg} \mathrm{BW}^{-1}$ higher in the vegetative stage of Alexandergrass.

The bite mass value observed was higher than the $0.30 \mathrm{~g}$ of organic matter considered limiting to the forage daily intake (STOBBS, 1973). Concerning grazing and idling behavior, bite rate and bite mass, heifers supplemented from Monday to Friday behaved similarly to those fed exclusively on Alexandergrass. This behavior occurred even at the evaluation date, when the heifers supplemented infrequently were receiving greater amounts of supplement compared to those that received supplement daily.

$\mathrm{BM}$ is the item that best explains the total ingestion of forage (total ingestion $=1.31+3.84$ BM; $p=0.0030 ; r^{2}=0.92$ ). Herbivores modify their feeding behavior to maintain a constant nutrient intake (HODGSON, 1990), which explains the similarity of total ingestion in the different supplementation frequencies. Bite mass and grazing time were similar for both phenological stages of Alexandergrass, whereas the bite rate was $17.0 \%$ lower in the reproductive stage. Bite rate is one of the mechanisms used to maintain nutrient intake.

Heifers supplemented from Monday to Friday consumed higher amounts of supplement in these days than heifers supplemented daily, and probably felt satiated with less forage ingestion. Information regarding metabolic state can be transmitted to the appetite control centers of the brain by a diverse array of signals, such as stimulation of the vagus nerve, or metabolic 'feedback' factors derived from the pituitary gland, adipose tissue, stomach/ abomasum, intestine, pancreas and/or muscle. These signals act directly on satiety control center of the brain (ROCHE et al., 2008). Also, heifers consumed $11.3 \%$ less grass in the Alexandergrass reproductive stage than in the vegetative stage, a decrease that can be related to a reduction of $48.9 \%$ in the leaf blades allowance, $62.5 \%$ in the leaf:stem ratio and $14.7 \%$ in in situ DM digestibility (Table 1). Besides the lower leaf:stem ratio, in the reproductive stage these leaves were located in the $0-10 \mathrm{~cm}$ stratum, limiting accessibility and consequently increasing in $4.8 \%$ the NDF content in forage as grazed. If the supplement is to be used as a tool to compensate a possible reduction of pasture intake, it should be increased by $0.14 \%$ of BW in the reproductive stage of Alexandergrass.

Heifers that remained exclusively on pasture had the forage intake influenced by the crude protein content $(\mathrm{CP})$ of forage as grazed, which is represented by the equation: Forage ingestion $=$ $7.4689-0.4395 \mathrm{CP} ; \mathrm{p}=0.0329 ; \mathrm{r}^{2}=0.93$. The amount of leaves in the canopy, the component with the highest CP content, assumes a greater importance to the animal performance when the animals are not supplemented.

FA $(r=0.89)$ and BR $(r=0.10)$ influenced forage ingestion of the daily supplemented heifers, according to the following equation: Forage ingestion $=1.4799+0.0116 \mathrm{BR}+0.08639 \mathrm{FA}$; $\mathrm{p}=0.0384 ; \mathrm{r}^{2}=0.99$. If forage allowance is kept constant, changes in pasture structure during the Alexandergrass cycle (Table 1) influence the heifers to modify the bite rate, which is one of the mechanisms used to maintain nutrient intake. If these heifers held a constant bite rate, the increase in forage allowance would provide an addition in forage intake. Indeed, forage allowance was 3.17 times higher than the forage intake estimated by NRC (2001) for this category. 
The forage intake of the heifers that received infrequent supplementation was influenced by bite rate (BR), according to the equation: Forage intake $=-2.0329+0.0964 \mathrm{BR} ; \mathrm{p}=0.0170 ; \mathrm{r}^{2}=0.97$. Bite mass was lower when the supplementation was infrequent, compared to daily supplemented heifers (Table 2). When variations in bite mass occur, bite rate is one of the herbivores' mechanisms to maintain forage ingestion relatively constant.

Protein intake from forage was negatively influenced by the number of steps performed between each feeding station (SFS), as indicated by the equation: Forage intake of $\mathrm{CP}=0.380-0.0051$ SFS; $p=0.0243 ; r^{2}=0.85$. To maintain the same forage intake of $\mathrm{CP}$ during the reproductive stage of Alexandergrass, heifers increased the time spent in each feeding station. Therefore, less feeding stations were visited per minute, keeping the number of steps between feeding stations similar in both phenological stages and supplementation frequencies, and decreasing heifers' displacement. This behavior characterizes an increased selectivity, explained in terms of reduction of leaf blades allowance and leaf: stem ratio along the Alexandergrass phenological cycle (Table 1).

The greater forage intake of heifers fed exclusively on pasture with similar NDF contents allowed a higher NDF intake by these heifers. NDF intake was similar in both grass phenological stages, with an average of $1.74 \mathrm{~kg} \mathrm{DM} 100 \mathrm{~kg}$ $\mathrm{BW}^{-1}$. The NDF content correlated negatively with forage protein content $(\mathrm{r}=-0.61 ; \mathrm{p}=0.0361)$. In order to maintain a similar ingestion of CP from forage, heifers grazing Alexandergrass, and those that received daily supplementation, harvested forage with lower crude protein content per bite, consequently harvesting higher NDF content.

The intake of total NDF was influenced by the bite mass (BM, $\mathrm{r}=0.79)$ and forage allowance (FA, $\mathrm{r}=0.16)$, represented by the equation: NDF intake $=$ $0.16+2.23 \mathrm{BM}+0.077 \mathrm{FA} ; \mathrm{p}=0.0127 ; \mathrm{r}^{2}=0.95$. The higher intake of total NDF by the daily supplemented heifers can be explained by the greater bite mass they harvested while grazing, added to supplement NDF content. In tropical pastures, increasing forage allowance provides an increment in the stems proportion in the grazeable stratum and a decrease in leaf:stem ratio, hindering the easiness of forage apprehension by the herbivore (STOBBS, 1975); thus, the animal will harvest a greater proportion of stems and consume a higher content of NDF.

The greater intake of forage, with similar NDF content, allowed a higher NDF intake by heifers in the vegetative phenological stage. NDF intake was similar in both grass phenological stages, with an average of $1.74 \mathrm{~kg} \mathrm{DM} 100 \mathrm{~kg} \mathrm{BW}^{-1}$. The NDF content showed negative correlation with forage protein content $(\mathrm{r}=-0.61 ; \mathrm{p}=0.0361)$. To maintain a similar forage ingestion of $\mathrm{CP}$, heifers grazing Alexandergrass and those who received daily supplementation harvested lower forage crude protein per bite.

Heifers receiving infrequent supplement harvest forage with higher crude protein content, and their grazing and idle time, as well as the bite mass, are similar to exclusively grazing animals. These animals remain longer per feeding season, and their forage and forage NDF intake is lower than those of heifers supplemented daily and of animals grazing exclusively.

\section{Conclusions}

In a similar sward structure, heifers on exclusive Alexandergrass pasture or given daily supplement had higher forage DM intake than heifers infrequently supplemented. Daily supplemented heifers spent less time grazing and harvested heavier bites. Heifers modified their total DM and forage intake as a response to changes in the sward structure, due to the grass phenological stages, but the ingestion of forage chemical components was similar. The multiple regression equations, which consider grass attributes, feeding behavior and 
displacement patterns in the Alexandergrass pasture, can be used as predictor models of dry matter intake of beef heifers on Alexandergrass pasture, receiving supplements under different frequencies.

\section{References}

ASSOCIATION OF OFFICIAL ANALYTICAL CHEMISTS - AOAC. Official methods of analysis. $16^{\text {th }}$ ed. Washington: AOAC, 995. 1025 p.

BARBER, W. P. B.; ADAMSON, A. H.; ALTMAN, J. F. B. New methods of feed evaluation. In: HARESIGN, W.; COLE, D. J. A. (Ed.). Recent advances in animal nutrition. London: Butterworths, 1984. p. 161-176.

BERCHIELLI, T. T.; CANESIN, R. C.; ANDRADE, P. Supplementation strategies for ruminants on pasture. Revista Brasileira de Zootecnia, Viçosa, MG, v. 35, p. 289-303, 2006.

CARVALHO, P. C. F.; PRACHE, S.; DAMASCENO, J. C. O. Processo de pastejo: desafios da procura e apreensão da forragem pelo herbívoro. In: REUNIÃO ANUAL DA SOCIEDADE BRASILEIRA DE ZOOTECNIA, 36., 1999. Porto Alegre. Anais... Porto Alegre: Universidade Federal do Rio Grande do Sul, 1999. p. 253-268.

CATON, J. S.; DHUYVETTER, D. V. Influence of energy supplementation on grazing ruminants: requirements and responses. Journal of Animal Science, New York, v. 75, n. 4, p. 533-542, 1997.

COSTA, V. G.; ROCHA, M. G.; PÖTTER, L.; ROSO, D.; ROSA, A. T. N.; REIS, J. Grazing behavior and forage ingestion by beef heifers on pearl millet and alexander grass pastures. Revista Brasileira de Zootecnia, Viçosa, MG, v. 40, n. 2, p. 251-259, 2011.

ELOY, L. R.; ROCHA, M. G.; PÖTTER, L.; FONSECA NETO, A. M.; BISCAÍNO, L. L.; ALVES, M. B.; GRAMINHO, L. A.; STIVANIN, S. C. B. Consumo de forragem por novilhas de corte recebendo farelo de arroz com e sem ionóforo. Ciência Rural, Santa Maria, v. 44, n. 7, p. 1223-1228, 2014.

EMPRESA BRASILEIRA DE PESQUISA AGROPECUÁRIA - EMBRAPA. Centro Nacional e Pesquisa em Solos. Sistema Brasileiro de Classificação de Solos. Brasília: Embrapa-SPI; Rio de Janeiro: EmbrapaSolos, 2006. 306 p.

EUCLIDES, V. P. B.; CARDOSO, E. G.; MACEDO, M. C. M.; OLIVEIRA, M. P. Consumo voluntário de Braquiaria decumbens cv. Basilisk e Braquiaria brizanta cv. Marandú sob pastejo. Revista Brasileira de Zootecnia, Viçosa, MG, v. 29, n. 1, p. 2200-2208, 2000.
FORBES, T. A. D. Researching the plant-animal interface: the investigation of ingestive behaviour of cows and sheep. Journal of Animal Science, Champaign, v. 66, n. 9 , p. $2369-2379,1988$.

FORBES, T. D. A.; HODGSON, J. Comparative studies on the influence of swards conditions on the ingestive behaviour of cows and sheep. Grass and Forage Science, Oxford, v. 40, n. 1, p. 69-77, 1985.

HERINGER, I.; CARVALHO, P. C. F. Ajuste da carga animal em experimentos de pastejo: uma nova proposta. Ciência Rural, Santa Maria, v. 32, n. 4, p. 675-679, 2002.

HODGSON, J. Grazing management: science into practice. Harlow: Longman Scientific \& Technical, 1990. $203 \mathrm{p}$.

INSTITUTO BRASILEIRO DE GEOGRAFIA E ESTATÍSTICA - IBGE. Produção Agrícola Mundial: área plantada, área colhida, quantidade produzida, rendimento médio e valor da produção das lavouras temporárias. Brasília: IBGE, 2011. Disponível em: <http://www.ibge. gov.br>. Acesso em: 21 out. 2011.

INSTITUTO NACIONAL DE METEOROLOGIA - INMET. Consulta de dados da estação automática. Brasília: INMET, 2011. Disponível em: <http://www. inmet.gov.br/portal/>. Acesso em: 15 out. 2011.

JAMIESON, W. S.; HODGSON, J. The effect of daily herbage allowance and sward characteristics upon the ingestive behaviour of calves under strip-grazing management. Grass and Forage Science, Oxford, v. 34, n. 4, p. 261-271, 1979.

JOCHIMS, F.; PIRES, C. C.; GLIEBER, L.; BOLZAN, A. M. S.; DIAS, F. D.; GALVANI, D. B. Feeding behavior and forage intake of ewe lambs on pearl millet pasture with or without supplementation. Revista Brasileira de Zootecnia, Viçosa, MG, v. 39, n. 3, p. 572-581, 2010.

KOMAREK, A. R. A fiber bag procedure for improved efficiency of fiber analyses. Jounal of Dairy Science, Champaign, v. 76, n. 1, p. 250, 1993. Supplement 1.

KOZLOZKI, G. V.; FLORES, E. M. M.; MARTINS, A. F. Use of chromium oxide in digestibility studies: variations of the results as a function of the measurement method. Journal of the Science of Food and Agriculture, New York, v. 76, n. 3, p. 373-376, 1998.

KRYSL, L. J.; HESS, B. W. Influence of supplementation on behavior of grazing cattle. Journal of Animal Science, Champaign, v. 71, n. 9, p. 2546-2555, 1993.

LACA, E. A.; UNGAR, E. D.; SELIGMAN, N. Effects of sward height and bulk density on bite dimensions of cattle grazing homogeneous sward. Grass and Forage Science, Oxford, v. 47, n. 1, p. 91-102, 1992. 
LOWMAN, B. G.; SCOTT, N.; SOMERVILLE, S. Condition scoring beef cattle. Edinburgh: East of Scotland College of Agriculture, $1973.8 \mathrm{p}$.

MANNETJE, L. T.; EBERSOHN, J. P. Relations between sward characteristics and animal production. Tropical Grassland, Camberra, v. 14, n. 3, p. 273-280, 1980.

NATIONAL RESEARCH COUNCIL - NRC. Nutrient requeriments of dairy cattle. $7^{\text {th }}$ rev. ed. Washington: The National Academies Press, 2001. 381 p.

OLIVEIRA NETO, R. A.; SILVA, J. H. S.; ROCHA, M. G.; PÖTTER, L.; SICHONANY, M. J. O.; BISCAÍNO, L. L.; SANTOS, F. A.; DIFANTE, M. V. B. Ingestive behavior, performance and forage intake by beed heifers on tropical pasture systems. Revista Brasileira de Zootecnia, Viçosa, MG, v. 42, n. 8, p. 549-558, 2013.

ØRSKOV, E. R.; MCDONALD, I. The estimation of protein degradability in the rumen from incubation measurements weighed according to rate of passage. The Journal of Agricultural Science, Toronto, v. 92, n. 2, p. 499-503, 1979 .

PENNING, P. D.; ROOK, A. J.; ORR, R. J. Patterns of ingestive behaviour of sheep continuously stocked on monocultures of ryegrass or white clover. Applied Animal Behaviour Science, Amsterdam, v. 37, n. 3, p. 237-250, 1991.

POND, K. R.; ELLIS, W. C.; MATIS, J. H. Passage of chromium-mordanted and rare earth-labeled fiber: time of dosing kinetics. Journal of Animal Science, Champaign, v. 67 , n. 4, p. 1020-1028, 1989.

PRACHE, S.; GORDON, I. J.; ROOK, A. J. Foraging behaviour and diet selection in domestic herbivores. Annales de Zootechnie, Les Ulis, v. 48, n. 5, p. 335-345, 1998.

ROBERTSON, J. B.; VAN SOEST, P. J. The detergent system of analysis. In: JAMES, W. P. T.; THEANDER, O. (Ed.). The analysis of dietary fibre in food. New York: Marcel Dkker, 1981. p. 123-158. (Chapter 9).

ROCHA, M. G.; PÖTTER, L.; ROSO, D. Sistemas intensivos de produção de gado de corte - ênfase recria de fêmeas. In: CICLO DE PALESTRAS EM PRODUÇÃO DE MANEJO DE BOVINOS, 12., 2007, Canoas. Palestras... Canoas: ULBRA, 2007. v. 1, p. 100-120.
ROCHE, J. R.; BLACHE, D.; KAY, J.; MILLER, D. R.; SHEAHAN, A. J.; MILLER, D. W. Neuroendocrine and physiological regulation of intake with particular reference to domesticated ruminant animals. Nutrition Research Reviews, London, v. 21, n. 2, p. 207-234, 2008.

SOLLENBERGER, L. E; MOORE, J. E.; ALLEN, V. G.; PEDREIRA C. G. S. Reporting forage allowance in grazing experiments. Crop Science, Madison, v. 5, n. 3, p. 896-900, 2005.

SOUZA, A. N. M.; ROCHA, M. G.; PÖTTER, L.; ROSO, D.; GLIENKE, C. L.; OLIVEIRA NETO, R. A. Ingestive behavior of beef heifers in warm season annual grass pastures. Revista Brasileira de Zootecnia, Viçosa, MG, v. 40, n. 8, p. 1662-1670, 2011.

SOUZA, A. N. M.; ROCHA, M. G.; ROSO, D.; PÖTTER, L.; ROSA, A. T. N.; ILHA, G. F.; CONFORTIN, A. C. C. Productivity and reproductive performance of grazing beef heifers bred at 18 months of age. Revista Brasileira de Zootecnia, Viçosa, MG, v. 41, n. 2, p. 306-313, 2012.

STOBBS, T. H. Factors limiting the nutritional value of grazed tropical pastures for beef and milk production. Tropical Grasslands, Brisbane, v. 9, n. 2, p. 141-150, 1975.

The effects of plant structure on the intake of tropical pastures. I Variation in the bite size of grazing cattle. Australian Journal of Agricultural Research, Melbourne, v. 24, n.6, p. 809-819, 1973.

VAN SOEST, P. J. Nutritional ecology of the ruminant. $2^{\text {th }}$ ed. London: Constock Publishing Associates, 1994. $476 \mathrm{p}$.

ZHOU, M.; ROBARDS, K.; GLENNIE-HOLMES, M.; HELLIWELL, S. Oat lipids. Journal of the American Oil Chemists' Society, Champaign, v. 76, n. 2, p. 159-169, 1999.

WELCH, J. G.; HOOPER, A. P. Ingestion of feed and water. In: CHURCH, D. C. (Ed.). The ruminant animal: digestive physiology and nutrition. Englewood Cliffs: Prentice Hal, 1988. p. 108-116. 
